next "Pharmacopœia". Dr. Hampshire exhibited specimens of these substances, classifying them in their appropriate groups. With regard to vitamins, he said the principal preparations of this group recommended for description are: Standardized concentrated solutions of vitamins $\mathrm{A}$ and $\mathrm{D}$; $\mathbf{a}$ vitaminized oil standardized to contain vitamins $A$ and $D$ in the proportion contained in a good average specimen of cod liver oil ; halibut liver oil containing not less than 30,000 units of vitamin A per gram; and pure crystalline aneurine hydrochloride to replace the adsorbate of vitamin $B_{1}$, described in the "Addendum; 1936".

Dr. Hampshire explained the reasons for some of the proposed additions to the "Pharmacopœia". Thus mandelic acid and calcium mandelate are both in use in the treatment of urinary infections; sulphanilamide is recommended as the best known member of the sulphonamide group which is free from patent complications; parachlorometacresol is recommended for use as a bactericide in sterilizing solutions for injection, and as a bacteriostatic preservative in certain solutions. $\mathrm{He}$ said that the proposed inclusion of the sera and other biologically tested preparations is necessary in order to bring this section of the work of the "Pharmacopœia" up to date. In this field the "Pharmacopœia" is kept closely in line with the regulations under the Therapeutic Substances Act; the regulations provide for the control of biologically tested substances in Great Britain and Northern Ireland, while the "Pharmacopceia" extends the control to other parts of the British Empire in which the "Pharmacopoia" is accepted as a legal standard. The revision has included a full review of all analytical procedure described in the various monographs and in the appendixes. In two directions a considerable increase in analytical methods is proposed : $(a)$ the addition of new tests and assays for galenical preparations and compounded drugs; and $(b)$ the addition, in a number of instances, of assays for the alkaloidal content of salts of various alkaloids.

\section{Astronomical Investigations of Horrox}

Prof. F. J. M. Stratron has published a very interesting and full account of the work of Horrox (Occas. Notes Roy. Astro. Soc., No. 7 ; 1939). To many astronomers, Horrox's fame rests almost entirely on his observation of the transit of Venus on November 24, 1639 (O.S.), his own calculations having shown an error in the Rudolphine tables, and also that a transit should take place on the above date. This was only a small part of his work, for, in addition to improving the tables then in existence, he was the first to show that the moon's orbit around the earth is an ellipse, the earth being at a focus. An excerpt from some of his writings at the age of eighteen shows that he anticipated Newton in connecting the movements of the planets with that of a body falling to the earth. The motion of the line of apses was explained by Horrox as due to the disturbing effect of the sun, and he was able to illustrate the idea by a simple pendulum experiment. In addition to his explanation of other difficulties connected with the motion of the moon, he detected the long inequalities in the opposite sense in the motions of Jupiter and Saturn, and he showed that comets move in elliptic orbits around the sun.

Although he undertook regular observations of the tides, no published work of Horrox on this subject survives, but he expressed the hope to Crabtree less than a month before his death that he would shortly detect the secret of the tides. Kepler's value of the distance of the sun was 3,500 times the earth's radius, and Horrox gave the value as 15,000 , that is, about two thirds the correct value. It is amazing that Newton adopted 5,000 fifty years later, instead of using Horrox's 15,000. When it is remembered that these results were obtained by one who had only attained the age of twenty-one and that he was practically self-taught and unaided, it is not surprising that astronomers have kept his name in affectionate remembrance for hundreds of years. What fields would Horrox have explored if he had not died at the early age of twenty-two in 1641 , the year before Newton was born? In 1874, when a transit of Venus occurred, a memorial was erected to him in Westminster Abbey, and over the monument are carved the words in which Horrox reported that he had abandoned the observations of the sun to carry out his spiritual duties in the Church.

\section{King Psusennes's Tomb at Tanis}

Now that the jewellery associated with the sarcophagus of King Psusennes at San el Hagar, in Lower Egypt, has been removed to the Cairo Museum, further details are becoming available which serve to indicate more fully the cultural and historical significance of the find. The similarity in the circumstances of discovery with those of the discovery of the tomb of Tutankhamen is striking. For years Lord Carnarvon and Howard Carter excavated in the Valley of the Kings without notable success until they made their great discovery. At Tanis, which had already been explored by both Mariette and Petrie with indifferent results, Prof. Montet pursued his investigation of the relics of the obscure Twentyfirst and Twenty-second Dynasties for nine years from 1929, before last year he made the remarkable discovery of the gold and silver sarcophagus of King Shishak, of the Twenty-second Dynasty, in the otherwise rifled tomb of King Psusennes, of the Twenty-first Dynasty.

The tomb of Psusennes, son of Smendes, founder of the Twenty-first or Tanite Dynasty, is situated in the temple of Rameses. It is of solid rose granite, it is stated in a communication from the correspondent of The Times in the issue of April 6, and is a few metres underground. Entrance is at present down a shaft about four metres deep through rock and sand. A small anteroom leads by a short passage, about two metres long, and hewn through solid granite, into the funerary chamber. This is also small, measuring only seven metres long by about three metres wide and high. The sarcophagus itself 
is $3 \frac{1}{2}$ metres long, and not less than $2 \frac{1}{2}$ metres wide. An unusual feature of the outer sarcophagus is the decoration on both the upper and under surface of the cover. On the upper surface is a full length image of the king dressed as Osiris. Broken features of the image of the inner sarcophagus suggest that it was damaged when being introduced into the tomb.

\section{Antiquity : a Sutton Hoo Number}

Antiquity of March last is devoted to a detailed account of the discovery, excavation and finds of the Sutton Hoo ship-burial. The excavation is described by Mr. C. W. Phillips, who points out that until 1939 the archæology of Britain in Anglo-Saxon times has had to concern itself little with either ship-burials or to a great extent with rich burials of any kind, for omitting those of Kent, and a few important burials at Taplow, Broomfield and elsewhere, the most striking feature of Anglo-Saxon graves is their almost universal poverty. In the more detailed description of the finds Mr. T. D. Kendrick gives accounts of the gold ornaments, the large hanging bowl and the jewellery; the silver is described by Mr. Ernst Kitzinger, and a summary account of the coins is contributed by the editor, Mr. O. G. S. Crawford. Mr. W. F. Grimes is responsible for a description of the methods followed in salvaging the finds, "an exciting and exacting task, extending over more than a week", in which he was first called to participate when the gold purse and its trappings had been found. Serious problems were presented by corrosion, but their solution called for no new and elaborate technical methods, but rather the application of simple readily available means to deal with an unexpected range of materials, each apart from the gold objects with its own set of problems. The identity of the individual whom the mound and its contents commemorated is discussed in full detail by Dr. H. Munro Chadwick, who accepts the possibility that it may have been the cenotaph of a king lost at sea-the editor of Antiquity here points out that there never has been question of a burial. After discussion of the various possibilities Dr. Chadwick elects for Redwald (ob. $c$. 624-5) as the most probable. The series of photographs accompanying these contributions constitutes a valuable record of this notable find.

\section{Indian Farming}

Thrs new monthly magazine, issued by the Imperial Council of Agricultural Research, replaces the bi-monthly Agricultural and Livestock in India, published by the Council since 1931. The aim of Indian Farming is to present scientific information in a popular form, and to form a link between the research worker and the cultivator. The format of the new journal is more pleasing than that of its predecessor and should appeal to a wider public. The contents include original articles on agricultural science, short notes on selected research work, reports from research stations, "answers to correspondents", practical hints to farmers, and book reviews. The popularization of agricultural science is a task as difficult as it is important, and the editorial committee is to be congratulated on its good beginning in seeking the happy mean between over- and under-simplification. The first article, by Sir Jagdish Prasad, on agricultural research in war, puts in a timely plea for the continuation of pure research during a period of stress when the demands for immediate results are most pressing.

\section{Fluorescent Enamel Paints}

THE Continental Lithograph Corporation, 952 East 72 nd Street, Cleveland, Ohio, has put on the market a series of 'enamel paints' (Conti-Glo Fluorescent Lacquer Enamels) with which brilliant fluorescence effects can be obtained when they are illuminated by radiation in the 'near ultra-violet'. Such a radiation can be conveniently obtained from tungsten filament lamps having bulbs of 'black' glass; these are supplied by the same Company. They are mounted in aluminium reflectors in order to concentrate the ultra-violet energy on the enamelled surface.

Tested with a mercury vapour lamp screened by a plate of ultra-violet transmitting glass, the samples appear to justify the maker's claims. The colours include white, pink, and orange, with various yellows, greens, and blues. Moreover, the fluorescent hue is markedly different in some cases from that of the paint in ordinary light; thus a cream paint becomes a green in the ultra-violet and a rose colour fluoresces red, while a white becomes a blue. These enamels have interesting possibilities for entertainment and decoration. They are said to be easily applied by ordinary spraying and brushing methods, and can even be applied (diluted with lacquer-thinner) to fabrics.

\section{Saliva Superstitions}

The December issue of Folk-Lore contains a richly documented article on this subject by Miss Rachel Sclare, of Leeds, who illustrates the medicinal and curative properties attributed to saliva throughout the ages and different parts of the world by quotations from the New Testament, the writers of classical antiquity (Theocritus, Tacitus and Pliny), the Middle Ages (Hildegarde of Bingen, Maimonides, and Albertus Magnus), and modern times (Brand, Tylor and Frazer). The diseases for which saliva has been used both as a curative and less frequently as a prophylactic measure are numerous, and include sore eyes, blindness, rheumatism, headache, toothache, warts, burns, wounds, etc. As a prophylactic, saliva has been employed as a protection against infectious diseases and as an antidote to poisons, as well as a means of averting ill-luck. The belief in the magical properties of saliva, which still-flourishes not only in primitive races but even in England as well as in other civilized countries, appears to be founded on the supposition that this secretion possesses a vital force closely connected with man's blood and the whole of his person.

\section{The Bed of Procrustes}

A WITTY and amusing paper with this title was read by Mr. Gordon D. Knox before a meeting of the Tenterden Toc H. (Tenterden : K. P. Press, 1940. 1s.). 